\title{
RANDOMNESS AND DETERMINISM: WHY ARE THE PLANETARY ORBITS ELLIPTICAL?
}

ŚLĄSKI

PRZEGLĄD

STATYSTYCZNY

Nr 12(18)

Oscar Sheynin

ISSN 1644-6739

Summary: I consider the interpretation of the notion of randomness in natural science from Aristotle to Poincaré, the interrelation between randomness and necessity according to Poincaré and the narrower understanding of randomness in the theory of probability and statistics. Kepler explained the ellipticity of the planetary orbits by random causes and Kant and Laplace largely followed him in spite of Newton who had established that ellipticities depended on the planets' velocity.

Keywords: Keplerian laws, planetary orbits, randomness and necessity, spontaneous generation, system of the world.

DOI: $10.15611 /$ sps.2014.12.03

\section{Randomness: General information}

Randomness is a fundamental notion. A popular discussion of recent mathematical efforts to define it, see Chaitin (1975). The history of that notion begins in antiquity. Indeed, Aristotle and other early scientists and philosophers attempted to define, or at least to throw light upon randomness. His examples of random events are a sudden meeting of two acquaintances (Phys. 196b30) and a sudden unearthing of a buried treasure (Metaphys. 1025a). In both cases the event occurred without being aimed at ( $\$ 1.3)$ and also, together with other cases, belongs to Poincaré's pattern of $\S 1.1$.

I have discussed Aristotle earlier (Sheynin 1974, § 2.2) but did not correctly interpret his explanation of the birth of female offspring. Concerning Kepler's explanation of the eccentricity of planetary orbits ( $\$ 2$ below), see also Sheynin (1974, § 8.1.1). I am referring to vol. 2 of Aristotle's Works edited by D. Ross (vols 1-12. Oxford, 1908-1954). Below, I refer to another of his contribution from vol. 8 of the same edition. There also exists an edition of Aristotle's Complete Works (vols 1-2. Princeton, 1984) whose composition is slightly different; the order of the contributions also differs, and the numbering of the pages and lines is therefore different. 
ŚLĄSKI

PRZEGLĄD

STATYSTYCZNY

Nr 12 (18) Many ancient authors had been repeating Aristotle's first example. Another example in which randomness was connected with lack of aim, appeared in the ancient Indian Yadrichchha or Chance Theory (Belvalkar \& Ranade 1927, p. 458):

The crow had no idea that its perch would cause the palm-branch to break and the palm-branch had no idea that it would be broken by the crow's perch; but it all happened by pure chance.

Then, Hobbes (1646/1840, p. 259) maintained that a traveller meets with a shower by chance since the journey caused not the rain, not the rain the journey.

Cournot (1843/1984, $\S 40$, p. 55) revived this interpretation:

Events occurring as a combination or meeting of phenomena which apparently belong to independent series [but] happening as ordered by causality, are called fortuitous, or results of hazard.

[Ces événements amenés par la combinaison ou la rencontre de phénomènes qui appartiennent à des séries indépendantes, dans l'ordre de la causalité, sont ce qu'on nomme des événements fortuits ou de résultats du hazard.]

Both examples actually illustrate one of Poincarés explanations (interpretations) of randomness (1907), then incorporated in his popular book (1908) and in his treatise: if equilibrium is unstable,

[a] very small cause which escapes us determines a considerable effect $[\ldots]$ and we say that that effect is due to chance.

[Une cause très petite, qui nous échappe, détermine un effet considérable [...] et alors nous disons que cet effet est dû au hazard] (Poincaré 1912/1987, p. 4).

Indeed, an insignificant delay of one of the two acquaintances (Aristotle) means that their meeting does not take place.

Poincaré could have just as well cited a coin toss. His deliberations (also see below) heralded the beginning of the modern period of studying randomness. However, Poincaré certainly had predecessors who only failed to mention directly randomness (Sheynin 1991, § 8). Among them was the ancient physician Galen (1951, p. 202): In old men even the slightest causes produce the greatest change; Pascal (1963, p. 549): Had Cleopatra's nose been shorter, the whole face of the Earth would have changed; and Maxwell (1873a, p. 364) who referred to the unstable refraction of rays within biaxial crystals. Elsewhere he (1859/1927, p. 295-296) left a most interesting statement (cf. § 1.7): 
There is a very general and very important problem in Dynamics. [...] It is this: Having found a particular solution of the equations of motion of any material system, to determine whether a slight disturbance of the motion indicated by the solution would cause a small periodic variation, or a total derangement of the motion.

\subsection{Corruption of/deviation from laws of nature}

Aristotle, whom we must continue to discuss, also explained the appearance of monsters (Phys. 199b1; De generatione anim. 767b5) as mistakes in the operation of nature; he says that the first

[d] eparture from the type is that the offspring should become female instead of male; [...] as it is possible for the male [for the father] sometimes not to prevail over the female [the mother] [...].

In my context, I should also mention Thomas Aquinas (Sheynin $1974, \S 2.4)$. His general goal was to unite faith and reason and to adapt pagan Aristotle to Christianity. He repeated the Philosopher's thoughts and mentioned some hindering cause (some corruption of law) bringing about the production of females.

Given a large number of births, regularities of mass random events will, however, certainly reveal themselves. Aristotle did not connect such events with randomness, a circumstance which his commentators had hardly indicated; moreover, he (De Caelo 283b1 and in other places) stated that the products of chance and fortune are opposed to what is, or comes to be, always or usually. Nevertheless, we are fully justified in calling them random: corruption of, or deviation from laws of nature also means randomness, and this idea can be traced at least until Lamarck who stated that the deviations from the divine lay-out of the tree of animal life had been occasioned by a cause accidentelle (Lamarck 1815, p. 133).

There also, on p. 173, he indicated that the spontaneous generation of organisms was caused by a très-irrégulière force but did not mention randomness.

\subsection{Lack of laws or purpose}

When considering the state of the atmosphere, Lamarck (An VIII, 1800, p. 76) stated that it was disturbed by two kinds of causes, including variables, inconstantes etirrégulières. Again, no mention of randomness, but then he (1810-1814/1959, p. 632) denied it: no part of nature disobeys invariable laws, therefore that, which is called chance, does not exist. Louis Pasteur definitively disproved spontaneous generation, 
ŚLĄSKI

PRZEGLĄD STATYSTYCZNY

Nr 12 (18) but I stress that until then it was apparently always considered random. Witness indeed Harvey (1651/1952, p. 338):

Creatures that arise spontaneously are called automatic [...] because they have their origin from accident, the spontaneous act of nature.

Harvey did not say anything about the essence of accidents, but it seems that he thought them aimless, identified them with lack of law. Many other scientists denied randomness as Lamarck did, see $\S 2$.

I will now mention Laplace (1814/1995, p. 9, my paraphrase) who stated that the arrangement of printed letters in the word Constantinople is not due to chance; all arrangements are equally unlikely, but that word has a meaning and it is incomparably more probable that someone had written it on purpose. He equated randomness with lack of purpose. This example shows that human judgement is needed for supplementing mathematical reasoning about randomness.

Note that Intersection of events ( $(1.1)$ can be additionally interpreted as lack of purpose.

\subsection{Separation of law and randomness}

In his main contribution to probability, the celebrated Doctrine of Chances, De Moivre (1756/1967, p. 329) considered as its main achievement the establishment of certain rules for estimating how far some sort of Events may rather be owing to Design than Chance. This is a quotation from the reprint of his Dedication of the first edition of the Doctrine of Chances to Newton. De Moivre also stated there that he should think himself

[v]ery happy if having given [...] a method of calculating the Effects of Chance [...] and thereby fixing certain Rules, for estimating how far some sorts of Events may rather be owing to Design than Chance, I could [...] excite in others a desire [...] of [...] learning from your [Newton's] Philosophy how to collect [...] the Evidences of exquisite Wisdom and Design, which appear in the Phenomena of Nature [...].

De Moivre did not define chance, but it seems to follow that if design (aim of nature) exists, then chance is its corruption; true, design is lacking in games of chance (which he studied), and its corruption is out of question: there, it was lack of any law.

I would say that all this testifies that for De Moivre the main goal of the emerging theory of probability was to study the deviations from the Divine laws of nature. In 1733, his derivation of the normal law of distribution (the first version of the central limit theorem) was occasioned 
by a study of the sex ratio at birth. For him, the initial binomial distribution of those births was a designed deterministic law of nature, the first statistical regularity of nature (with its parameter only STATYSTYCZNY approximately known) and only the actual deviations from it were random in the mathematical sense. See the final version of that derivation (De Moivre 1756/1967, pp. 252-253). This is indeed interesting for the history of probability theory.

Poincaré also formulated a dialectical statement about determinism and randomness much broader than the one following from deviation from laws of nature: it legitimizes randomness and indirectly defines it but does not say anything about regularities of mass random events:

In no field [of science] do exact laws decide everything, they only trace the boundaries within which randomness is permitted to move. According to this understanding, the word randomness has a precise and objective meaning.

[Dans chaque domaine, les lois précises ne décidaient de tout, elles traçaient seulement les limites entre lesquelles il était permis au hazard de se mouvoir. Dans cette conception, le mot hazard avait un sens précis, objectif] (Poincaré 1896/1912, p. 1).

Poincaré's pronouncement restricted the action of his pattern small cause - considerable effect $(\S 1.1)$. Exact laws tolerate randomness. Indeed, here is Newton (1704/1931, Query 31):

Blind fate could never make all the planets move one and the same way in orbs concentric, some inconsiderable irregularities excepted, which may have risen from the mutual actions of comets and planets upon one another, and which will be apt to increase, till this system must be allowed the effect of choice.

Perturbations have appeared here just as errors of observations did in Poincaré's reasoning. Thus, Newton actually recognized randomness, although this time only in its uniform version as witnessed by the expression blind fate. Whether in English, or in equivalent French and German terms, scientists of the $17^{\text {th }}$ and $18^{\text {th }}$ centuries, if discussing randomness, mostly understood it in this sense, see also end of $\S 1.9$. For example, Arbuthnot (1712), unlike De Moivre, only compared Design with a discrete uniform distribution of the sexes of the newborn.

Newton (Sheynin 1971), however, considered throws of an irregular die. In this case and in a separate thought experiment he suggested an embryo of the Monte Carlo method. I briefly add that he also introduced geometric probability, cf. § 1.9. Maupertuis (1745/1756, pp. 120-121) indicated that the seminal liquid of chaque individu most often contained 
ŚLĄSKI

PRZEGLĄD STATYSTYCZNY

Nr 12 (18) parties similar to those of their parents, but he (p. 109) also mentioned rare cases of a child resembling one of his remote ancestors as well as mutations (p. 121, a later term). It seems that Maupertuis thus recognized randomness with a multinomial distribution, but, when discussing the origin of eyes and ears in animals, he (1751/1756, p. 146) only compared une attraction uniforme \& aveugle and quelque principe d'intelligence (and came out in favour of design).

\subsection{Formidable effect of a large number of small causes}

I return to Poincaré, to his statement first pronounced in 1907: he (1912/1987, p. 10) attributed accidental errors of observation to chance since

Their causes are too complicated and too numerous. Here again we only have small causes each of them [now, contrary to his previous definition,] only producing a small effect; it is because of their combination and their number that their effect becomes formidable.

[Nous les attribuons au hazard, parce que leurs causes sont trop compliquées et trop nombreuses [...] nous n'avons que de petites causes, mais chacune d'elles ne produit qu'un petit effet; c'est par leur union et par leur nombre que leurs effets deviennent redoutables.].

Here, variations between individuals of a given species, or once more coin tosses could have been cited.

\subsection{Laplace: impossible condition for lack of randomness}

Laplace $(1814 / 1995$, p. 2) stated that, for a mind, able to comprehend all the natural forces, and to submit these data to analysis, there would exist no randomness and the future, like the past, would be open to it. My example: the outcome of a coin toss will then be predicted, cf. Poincaré's statement ( $(1.5)$ about errors of observation.

Nowadays, this opinion cannot be upheld because of the recently discovered phenomenon of chaos, see below. Other remarks are also in order. Such a mind does not exist (so that Laplace's statement was purely academic) and there are unstable movements, sensitive to small changes of initial conditions. And I also note that already previous scholars, for example, Maupertuis (1756, p. 300) and Boscovich (1966, $\S 385)$, kept to the "Laplacean determinism". Both mentioned calculations of past and future (to infinity on either side, as Boscovich maintained) but both disclaimed any such possibility.

The main pertinent point is, however, that Laplace had actually recognized randomness. Without applying stochastic methods he would 
have not been engaged in studying and furthering the theory of probability, and neither would have he been able to achieve brilliant success in astronomy. Here is an example (regrettably the only direct STATYSTYCZNY confirmation of the above): a certain astronomical magnitude

Although indicated by observations, was neglected by most astronomers because, as it seemed, it did not follow from the theory of universal attraction. Nevertheless, subjecting [the probability of] its existence to the Calculus of Probabilities, I determined that its probability was very high, and considered myself obliged to study its cause.

[quoique indiquée par les observations, était négligée par le plus nombre des astronomes, parce qu'elle ne paraissait pas résulter de la théorie de la pesanteur universelle. Mais, ayant soumis son existence au Calcul des Probabilités, elle me parut indiqués avec une probabilité si forte, que je crus devoir en rechercher la cause] (Laplace 1812/1886, p. 361).

\subsection{Chaotic processes}

A chaotic process engendered by a small corruption of the initial conditions of motion can lead to its exponential deviation. Only in a sense this may be understood as an extension of Poincaré's pattern small cause - considerable effect ( $§ 1.1)$. However complicated and protracted is a coin toss, it has a constant number of outcomes whose probabilities persist, whereas chaotic motions imply rapid increase of their instability with time and countless positions of their possible paths. Their importance in mechanics and physics is unquestionable.

My explanation of the comparatively new concept is only qualitative, but still much better than those, offered by previous authors. Thus, Ekeland (2006, p. 125) unfortunately likened that process with a game of chance whereas the main point is, to separate these notions.

\subsection{Random variables in natural sciences and in statistics}

This subsection seems necessary for completing the discussion of randomness. In statistics, a random variable should be statistically stable, but in natural science this restriction is not necessary. An approach to that distinction was due to Poincare (1896/1923, p. 3):

Among the phenomena whose causes are unknown to us, we ought to distinguish random phenomena, about which we initially find out by the calculus of probability, and non-random, about which we cannot say anything. 
ŚLĄSKI

PRZEGLĄD STATYSTYCZNY

Nr 12 (18)

[Parmi les phénomènes dont nous ignorons les causes, nous devions distinguer les phénomènes fortuits, sur lesquels le calcul des probabilités nous renseignera provisoirement, et ceux qui ne sont pas fortuits et sur lesquels nous ne pouvons rien dire.]

Lamarck (see end of $\S 1.2$ ) provided a good example of the latter phenomena: the deviations from the divine lay-out of the tree of animal life. Without mentioning Poincaré Kolmogorov (1983/1992, p. 515) more properly stated:

We should distinguish between randomness in the wider sense (absence of any regularity) and stochastic random events (which are the subject of probability theory).

There seems to be no quantitative criteria of statistical stability, and, anyway, practice often has to work in its absence; example: sampling estimation of the content of the useful component in a deposit. However, choose other sample points, and it will be unclear whether they possess the same statistical properties (Tutubalin 1972/2011, § 1.2). But, according to scientific folklore, pure science achieves the possible by rigorous methods, applications manage the necessary by possible means ... Statistical stability apparently characterizes phenomena which can be studied by observations belonging to a single law of distribution, to a single population. I refer to this statement at the end of $\S 1.9$ and I note that it specifies the problem of the probability of a single event. Mises is known to have denied the possibility of studying single events whereas Markov (1911/1981, p. 150) emphasized that without probabilities of events on separate trials there is no law of large numbers. For probability theory to study separate trials they should correspond to stochastic random events.

Bayes is known to have introduced a very special type of randomness. He regarded an unknown constant as a random variable with a uniform distribution and his approach persisted in spite of previous prolonged fierce opposition. Obviously, his pertinent trials were statistically stable.

I provide now an example of a false conclusion caused by lack of statistical stability of the considered deviations. William Herschel (1817/1912, p. 579), who certainly knew nothing either about the size of stars or of their belonging to different spectral classes, decided that the size of a randomly chosen star will not much differ from the mean size of all of them. The sizes of stars are enormously different and their mean size is a purely abstract notion. There are stars whose radii are greater than the distance between the Sun and the Earth.

Earlier, De Moivre (1733/1756, pp. 251-252) refused to admit randomness in the wide sense in mathematical considerations: 
Absurdity follows, if we should suppose the Event not to happen

according to any Law, but in a manner altogether desultory and STATYSTYCZNY uncertain; for then the Event would converge to no fixed Ratio at all.

\subsection{Geometric probability and the random chord}

I am briefly repeating the contents of my paper (2003) and adding an important conclusion.

Many scholars had been time and time again unconscientiously introducing geometric probability. Thus, in 1743 De Moivre described the probability of life's failing during a given time by the ratio of certain segments. John Michell, in 1767, discussed the probability that two stars out of their multitude scattered over the sky by mere chance were close to each other. In 1868 Boltzmann defined the probability that the velocity of a molecule was contained in an infinitesimal interval as the ratio of the time during which this took place to the total time of observation (the time average probability). Buffon, in 1777, forcefully introduced geometrical probability intending to put geometry in possession of its rights in the science of chance. His needle problem became the talk of the town.

One upshot of the developments in the $19^{\text {th }}$ century was Bertrand's discovery (1888, pp. 4-5) that the notion of uniform randomness (uniform density of the appropriate probabilities) was not specific enough and allowed numerous interpretations. What was the probability $(p)$, he asked, that a randomly drawn chord of a given circle with radius $r$ was longer than the side of an equilateral triangle inscribed in that circle.

He considered three natural ways of specifying the chord (e.g., its direction was fixed) and arrived at three different answers. Poincaré (1896, p. 97/1912, p. 119) showed that Bertrand had actually considered different problems. Thus (one of his examples), he chose the centre of the circle as the origin of a system of polar coordinates, and one of its diameters as the polar axis, denoted the coordinates of the centre of the chord by $\theta$ and $\rho$ (also see below) and arrived at $p=1 / 2$.

Prokhorov (1988), although without providing any value for $p$, decided that the most natural assumption for solving the Bertrand paradox was to choose those same coordinates, independent and uniformly distributed.

Many other commentators also tackled that problem. In 1908 Czuber discovered its three more natural versions. Otto Schmidt, in a Russian paper of 1929 , stipulated that the probability sought should 
ŚLĄSKI

PRZEGLĄD STATYSTYCZNY

Nr $12(18)$ persist under translation and rotation of the coordinate system (reflection is now also included) and found that $p=1 / 2$.

De Montessus (1903), although making an elementary mathematical mistake, broke new ground. Suppose, as he did, that a point, through which the chord is passing, is moving along a diameter of the circle. Denote its distance from the centre of the circle by $x$. A certain probability will correspond to each point of interval $0 \leq x<\infty$ and its mean value will be $1 / 2$; indeed, at large values of $x$ that probability approximates $1 / 2$. Note that the set of possible probabilities is here uncountable. In the interval $0 \leq x \leq r / 2$ any random chord would have satisfied the stipulated condition, so that it is methodically proper to consider the interval $r / 2 \leq x \leq \infty$, but the answer is the same in both cases.

Various authors thus opted for $p=1 / 2$. However, according to the theory of information (Brillouin 1956, p. 1 of main text, somewhat obliquely) that value of probability is tantamount to complete ignorance; Ex nihilo nihil fit, end of discussion! Kolmogorov's statement in $\S 1.8$ means that, at least in case of "uniform" randomness (of the Bertrand chord), an incomplete knowledge of the uniformity leads to randomness in the wider sense.

Here is a similar example (Poisson 1837, p. 47). An urn contains a finite number of white and black balls in an unknown proportion. The subjective (!) probability of extracting a white ball was $1 / 2$, and his reasoning could have been applied to the probability of the outcome of a coin toss.

Bertrand's problem was characteristic of the former widespread restriction of randomness to "uniform" randomness. While illustrating this idea, both J.F. Herschel (lecture 1861/1866) and Baer (1873, p. 6) mentioned the philosopher depicted in Gulliver's Travels. Hoping to get to know all the truths, this good-for-nothing inventor put on record each sensible chain of words which happened to appear among their uniformly random arrangements. Baer thus argued that evolution of species was impossible.

\section{Kepler}

Kepler only formally denied randomness:

What is, however, randomness? Indeed, the most disgusting idol, nothing but an insult to God, Sovereign and Almighty, as well as to the most perfect world that He created.

[Was aber ist Zufall? Wahrlich, er ist ein höchst abscheulicher Götze und nichts anderes als eine Beschimpfung des höchsten und allmächtigen 
Gottes und der höchst vollkommenen Welt, der er schuf] (Kepler 1606/2006, p. 163).

Kepler was neither the first, nor the last to deny randomness. STATYSTYCZNY Nr 12 (18) Aristotle banished it from science by stating that "None of the traditional sciences busies itself about the accidental [...] but only sophistry" (Metaphysica 1064b15). He was wide of the mark: the theory of probability "busies itself" not about the accidental, but about its laws. Then, Laplace (1776/1891, p. 145) stated that chance has no reality in itself (n'a aucune réalité en lui-même), it only signified our ignorance. And Darwin (1859/1964, Chapt. 5, p. 131) thought that variations in his theory were not at all due to chance, that such an expression only acknowledged our ignorance of the proper causes. Even Boltzmann hesitated to acknowledge randomness.

In astrology, Kepler considered himself the founder of its scientific direction, of studies of the qualitative correlation between heavenly forces and events occurring on the Earth. Leaving aside his predecessors (for example, Ptolemy and Tycho Brahe), I quote his typical statement:

An astrologer who only sees the sky but [...] does not know anything about intermediate causes can only forecast probably [...] which means a bit better than not at all.

[Ein Astrologus, der nur den Himmel sihet und von [...] zwischenursachen nicht weiss, nur allein probabiliter [...] das ist, ein klein wenig mehr dann nichts] [...] Kepler (1610/1941, p. 217).

Probably is not definite enough, but the main point is that Kepler actually recognized randomness as corruption of law (§ 1.2).

I (Sheynin 1974, § 7) treated Kepler's astrology in much more detail, but now I turn to astronomy, and namely to the problem of eccentricities of the planetary orbits. At first, Kepler understood eccentricity as the preordained eccentric position of the Sun as measured from the centre of the circular orbit of a given planet. He then changed his (actually, ancient) definition and stated that eccentricity depended on the combination of external forces, see below.

Kepler (1596/1963) first encountered those eccentricities when attempting to construct a model of the solar system by inserting the five regular solids between the spheres of the then six known planets: they, the eccentricities, and, for that matter, unequal one to another, much worried him: The causes of the eccentricities are not yet studied, and neither are their differences [Die Ursache der Excentrizitäten wie auch ihrer Unterschiede noch nicht erforscht ist] (Chapter 18, p. 111).

In Chapter 17, p. 108, he formulated the problem for those interested: To discover these causes by issuing from the regular solids. God, he 
ŚLĄSKI

PRZEGLĄD STATYSTYCZNY

Nr 12 (18) added, did not assign the eccentricities accidentally. In the second edition of that contribution Kepler provided Notes to almost each chapter, and we find there that that problem was not solved [by his predecessors] (p. 117) but that he had investigated it, and look, I have [he had] revealed the main [vorzüglichsten] causes (p. 118 with a reference to Book 5 of his Harmony (1619)).

Here is the title of one of the chapters of that contribution:

The origin of the eccentricities of the individual planets [is] in the arranging of the harmonies between their motions (Kepler 1619/1997, title of Chapter 9 of Book 5 on p. 451).

On that same page he explained that God had combined the planetary motions with the five regular solids and thus created the only most perfect prototype of the heaven.

Again in the same chapter, in Proposition 5, on p. 454, he indirectly mentioned in this connection his second law of planetary motion; for that matter, he could have referred to it in his Epitome (1618-1621). Even admitting his theory of solids, which definitively fell down after the discovery of the seventh planet (Uranus), we see, however, that Kepler did not explain the values of those eccentricities. In other words, randomness persisted in spite of his efforts, and its cause was left obscure.

In his main work, Kepler indicated that

[e]xamples of natural things, and the kinship of celestial things for these terrestrial ones [...], cry out that [...] the variables, if any (such as, in the motion of the planets, the varying distance from the sun, or the eccentricity [which explains why do the distances vary] arise from the concurrence of extrinsic causes (Kepler 1609/1992, Chapter 38, pp. 404-405).

On the same page 405 he illustrated his opinion by obstacles which prevent rivers from descending towards the centre of the earth, and finally, on the next page, he concluded that other causes are conjoined with the motive power from the sun [affect their motion], cf. deviation from laws of nature (§ 1.2).

Kepler (1618-1621, 1620/1952, Book 4, pt. 3, § 1, p. 932) voiced his main statement in a later contribution:

If the celestial movements were the work of mind, as the ancients believed, then the conclusion that the routes of the planets are perfectly circular would be plausible. [...] But the celestial movements are [...] the work of [...] nature [...] and this is not proved by anything more validly than by observation of the astronomers, who [...] find that the 
elliptical figure of revolution is left in the real and very true movement

of the planet. [...] Because in addition to mind there was then need of natural and animal faculties [which] followed their own bent [...] [and] STATYSTYCZNY did many things from material necessity. So it is not surprising if those faculties, which are mingled together, could not attain perfection completely. The ancients themselves admit that the routes of the planets are eccentric, which seems to be a much greater deformity than the ellipse.

Or, more subtly: attempts to obey laws of nature which are, however, too complicated to follow, involve those same deviations.

\section{Kant and Laplace}

\subsection{Kant}

I do not know if or to what extent had Kant borrowed from Kepler, but in any case he held to external influences, - again to deviations or complications preventing obedience to laws of nature $(\S 1.2)$ :

The multitude of circumstances that participate in creating each natural situation, does not allow the preordained regularity to occur.

[Die Vielheit der Umstände, die an jeglicher Naturbeschaffenheit Anteil nehmen, eine abgemessene Regelmäßigkeit nicht verstattet] (Kant 1755/1910, 1. Hauptstück, p. 269).

Why are their [the planets'] paths not perfectly circular? Is it not seen clearly enough, that the cause that established the paths of celestial bodies [...] had been unable to achieve completely its goal? [...] Do we not perceive here the usual method of nature, the invariable deflection of events from the preordained aim by various additional causes?

[Woher sind ihre Umläufe nicht vollkommen zirkelrund? [...] Ist es nicht klar einzusehen, dass diejenige Ursache welche die Laufbahne der Himmelkörper gestellet hat, [...] es nicht völlig hat ausrichten können [...]. Ist nicht das gewöhnliche Verfahren der Natur hieran zu erkennen, welches durch die Dazwischenkunst der verschiedenen Mitwirkungen allemal von der ganz abgemessenen Bestimmung abweichend gemacht wird?] (Kant 1755/1910, 8. Hauptstück, p. 337).

\subsection{And now I turn to Laplace}

Had the Solar system been formed perfectly orderly, the orbits of the bodies composing it would have been circles whose planes coincide with the plane of the Solar equator. We can perceive however that the countless variations that should have existed in the temperatures and 
densities of the diverse parts of these grand masses gave rise to the eccentricities of their orbits and the deviations of their movement from the plane of that equator.

[Si le système solaire s'était formé avec une parfaite régularité, les orbites des corps qui le composent seraient des cercles, dont les plans, ainsi que ceux des divers équateurs et des anneaux, coïncideraient avec le plan de l'équateur solaire. Mais on conçoit que les variétés sans nombre qui ont dû exister dans la température et la densité des diverses parties de ces grandes masses ont produit les excentricités de leurs orbites, et les déviations de leurs mouvements du plan de cet équateur] (Laplace 1884, Note 7, p. 504; first published 1796 and many times reprinted).

The causes mentioned by Laplace could have hardly be called external, but one of the main relevant explanations of randomness, deviation from the laws of nature $(\S 1.2)$, persisted.

\section{Newton}

Newton theoretically proved that the Keplerian laws of planetary motion resulted from his law of universal gravitation. In my context, it is necessary to stress: it is generally known that he also established that the eccentricity of the orbit of a given planet was determined by the planet's initial velocity. For some greater values of that velocity the orbit will become parabolic (with its eccentricity $\varepsilon$ equal to unity, not less than unity as in the case of ellipses), for other still greater values, hyperbolic (with $\varepsilon>1$ ). And for a certain value of that velocity an elliptic orbit will become circular. And it is difficult to imagine that such changes do not occur gradually, that, consequently, the eccentricity does not vary continuously with the velocity. This discovery certainly does not contradict Newton's statement about perturbations ( $§ 1.4)$.

All these findings, as Newton proved, persisted for planets (not material points) having a regularly variable density. I believe that irregular variations of densities (but hardly temperatures) peculiar to a given planet (Laplace) could have only somewhat corrupted the eccentricity caused by its initial velocity and in any case Laplace did not provide any calculations.

\section{Discussion}

In spite of his formal denial of randomness, Kepler had at least sometimes actually acknowledged it. Whatever he could have thought, his laws did not explain the values of the eccentricities. But it really 
seems that Laplace (and Kant) were mistaken (Kepler was obviously ignorant of the law of universal gravitation). I am not sure that Kant had studied Newton attentively enough, but Laplace certainly did (but only STATYSTYCZNY after 1813, see Bibliography).

Witness finally Fourier's comment (1829, p. 379) on Laplace's Exposition: it is an ingenious epitome of the principal discoveries. And on the same page, discussing Laplace's historical works (to whose province the Exposition belonged):

If he writes the history of great astronomical discoveries, he becomes a model of elegance and precision. No leading fact ever escapes him. [...] Whatever he omits does not deserve to be cited.

Did Fourier note Laplace's mistake? Or, was he also still ignorant of the real cause of eccentricities?

Newton had indeed explained why are the planetary paths eccentric, but did he eliminate chance? No, not at all! Indeed, a similar question remains about the planetary velocities: why are they different? I do not know whether this question was formulated earlier.

I have only touched on the general problem of the role of randomness in natural sciences and only allow myself one pertinent reference (out of several possible) to Maxwell (1873b, p. 274) which also shows that randomness is not at all banished from the system of the world:

The form and dimension of the orbits of the planets [...] are not determined by any law of nature, but depend upon a particular collocation of matter. The same is the case with respect to the size of the earth.

I prefer to say: the particular arrangement of matter and velocities in the Solar system.

Acknowledgement. This is a completely rewritten version of my former paper (1991). Now, I am grateful to Professor G. Tee (Auckland, N. Z.) for helpful comments on a previous version of this new paper and especially to the referee whose remarks compelled me to change and specify somewhat my exposition. Its Russian version was published in Voprosy Istorii Estestvoznania i Tekhniki No. 2, 2011, pp. 36-44.

\section{References}

Arbuthnot J. (1712), An argument for Divine Providence taken from the constant regularity observed in the birth of both sexes. In Kendall M.G., Plackett R.L., Editors (1977), Studies in the History of Statistics and Probability, vol. 2. London, pp. 30-34.

Baer K. (1873), Zum Streit über den Darwinismus. Dorpat. 
Belvalkar S.K., Ranade R.D. (1927), History of Indian Philosophy, vol. 2. Poona.

Bertrand J. (1888), Calcul des probabilités. Second edition 1907. Reprint of first edition: Nr 12 (18) New York, 1970.

Boscovich, R. (1758, in Latin/1966), Theory of Natural Philosophy. Cambridge, Mass.

Brillouin L. (1956), Science and Information Theory. New York. [New York, 1962.]

Campbell L., Garnett W. (1882), Life of Maxwell. London. [London, 1884; New York-London, 1969.]

Chaitin G.J. (1975), Randomness and mathematical proof. Scient. American, vol. 232, pp. $47-52$.

Cournot A.A. (1843), Exposition de la théorie des chances et des probabilités. Paris, 1984.

Darwin C. (1859/1964), Origin of Species. Cambridge, Mass.

De Moivre A. (1718), Doctrine of Chances. New York, 1967. A reprint of the third edition of 1756 .

- $\quad$ (1733, Latin), A method of approximating the sum of the terms of the binomial $(a+b)$ ${ }^{n}$ expanded into a series from whence are deduced some practical rules to estimate the degree of ascent which is to be given to experiments. Translated by author, incorporated in the second edition of the Doctrine (1738) and in extended form in its third edition (1756/1967, pp. 243-254).

De Montessus R. (1903), Un paradoxe du calcul des probabilités. Nouvelles annales mathématiques, sér. 4, t. 3, pp. 21-31.

Ekeland I. (2006), The Best of All Possible Worlds. Mathematics and Destiny. ChicagoLondon.

Fourier J.B.J. (1829), Historical Eloge of the Marquis De Laplace. London, Edinb. and Dublin Phil. Mag., ser. 2, vol. 6, pp. 370-381. The original French text was only published in 1831 .

Galen C. (1951), Hygiene. Springfield, Illinois.

Great Books (1952), Great Books of the Western World, vols 1-54. Chicago.

Harvey W. (1651 in Latin), Anatomical Exercises in the Generation of Animals. In Great Books (1952, vol. 28, pp. 329-498).

Herschel J.F. (lecture 1860). Sun. In author's Familiar Lectures on Scient. Subjects. London-New York, 1866, pp. 47-90.

Herschel W. (1817), Astronomical observations and experiments tending to investigate the local arrangement of celestial bodies in space. In author's Scient. Papers, vol. 2. London, 1912. Reprinted: Bristol, 2003.

Hobbes T. (1646), Of liberty and necessity. Engl. Works, vol. 4. London, 1840, 229-278.

Kant I. (1755), Allgemeine Naturgeschichte und Theorie des Himmels. In author's Ges. Schriften, Abt. 1, Bd. 1. Berlin, 1910, pp. 215-368.

Kepler J. (1596), Mysterium Cosmographicum. Ges. Werke, Bd. 8. München, 1963, pp. 7-128. The 1963 version is a reprint of the second edition of 1621 with additions having been inserted by Kepler to the first edition to many chapters. German translation: Augsburg, 1923; München-Berlin, 1936.

- $\quad$ (1606, in Latin), Über den Neuen Stern im Fuß des Schlangenträger. Würzburg, 2006.

- $\quad$ (1609, in Latin), New Astronomy. Cambridge, 1992.

- (1610), Tertius interveniens. In author's Ges. Werke, Bd. 4. München, 1941, pp. 149-258. In German.

- (1619, in Latin), Harmony of the World. Philadelphia, Book 5, 1997. German translation: Münich-Berlin, 1939.

- (1620-1621, in Latin), Epitome of Copernican Astronomy, books 4-5. In Great Books (1952, vol. 16, pp. 845-1004). 
Kolmogorov A.N. (1983), On the logical foundations of probability theory. Sel. Works, vol. 2. Dordrecht, 1992, pp. 515-519.

Lamarck J.B. (an 8, 1800), Annuaire météorologique, t. 1. Paris.

- (1810-1814, manuscript), Aperçu analytique des connaissances humaines. Partly published: Vachon M. et al. (1972), Inédits de Lamarck. Paris, pp. 69-141. Russian translation of entire work to which I refer is in author's Izbrannye Proizvedenia (Sel. Works), vol. 2. Moscow, 1959, pp. 93-662.

- $\quad$ (1815), Histoire naturelle des animaux sans vertèbres, t. 1. Paris.

Laplace P.S. (1776), Recherches sur l'intégration des equations différentielles. Oeuvr. Compl., t. 8. Paris, 1891 , pp. 69-197.

- $\quad(1796,1798 / 1799,1808,1813,1835)$, Exposition du système du monde. Oeuvr. Compl., t. 6. Paris, 1884 .

- (1812), Théorie analytique des probabilités. Oeuvr. Compl., t. 7. Paris, 1886.

- $\quad$ (1814, in French), Philosophical Essay on Probabilities. New York, 1995.

Markov A.A. (1911, in Russian), On the basic principles of the calculus of probability and on the law of large numbers. In Ondar Kh.O., Editor (1977, in Russian), The Correspondence between A.A. Markov and A.A. Chuprov etc. New York, 1981, pp. 149-153.

Maupertuis P.L.M. (1745), Venus physique. Oeuvres, t. 2. Lyon, 1756, pp. 1-133.

- (1751), Système de la nature. Ibidem, pp. 135-184.

- (1756), Sur le divination. Ibidem, pp. 298-306.

Maxwell J.C. (1859), On the stability of the motion of Saturn's rings. Scient. Papers, vol. 2. Paris, 1927 , pp. 288-376.

- $\quad($ read 1873, 1873a), Does the progress of physical science tend to give any advantage to the opinion of necessity [...] over that of contingency of events. In Campbell \& Garnett (1882, pp. 357-366).

- (1873b, manuscript; publ. 1882), Discourse on molecules. In Campbell \& Garnett (1882, pp. 272-274).

Newton I. (1704), Opticks. London, 1931. Queries were added later, from 1717 onward, and the edition of 1931 (reprinted in 1952) was based on that of 1730 .

Pascal B. (1963), Pensées, fragment 413-162. Oeuvr. Compl. Paris, pp. 493-649.

Poincaré H. (1896), Calcul des probabilités. Paris. Second edition, 1912, reprint Sceaux, 1987.

- (1907), Le hazard. La Rev. du Mois, t. 3, pp. 257-296.

- (1908), Science et méthode. Paris.

Poisson S.-D. (1837), Recherches sur la probabilité des jugements, principalement en matière criminelle et en matière civile. Paris. [Paris, 2003.]

Prokhorov You.V. (1988), The Bertrand paradox. Encyclopedia of Mathematics, vol. 1. Dordrecht, pp. 370-371.

Sheynin O. (1971), Newton and the classical theory of probability. Arch. Hist. Ex. Sci., vol 7, pp. 217-243.

- (1974), On the prehistory of the theory of probability. Arch. Hist. Ex. Sci., vol. 12, pp. $97-141$.

- (1991), The notion of randomness from Aristotle to Poincaré. Math., Inform., Sci. Hum., 29 année, No. 114, pp. 41-55. Also in my Russian Papers on the History of Probability and Statistics. Berlin, 2004 and at www.sheynin.de.

- (2003), Geometric probability and the Bertrand paradox. Historia Scientiarum, vol. 13 , pp. 42-53.

Tutubalin V.N. (1972, Russian), Theory of probability in natural science. In: Studies in the History of Statistics and Probability, vol. 2. Berlin, 2011, pp. 7-56. Also at www. sheynin.de. 


\section{ŚLĄSKI PRZEGLĄD STATYSTYCZNY \\ LOSOWOŚĆ I DETERMINIZM. DLACZEGO ORBITY PLANET SĄ ELIPTYCZNE? \\ Nr 12 (18)}

Streszczenie: W pracy wyjaśniono pojęcie losowości w naukach przyrodniczych od czasów Arystotelesa do Poincarégo. Wyjaśniono związek między losowością i koniecznością w ujęciu Poincarégo, a także bardziej wąskie rozumienie tych pojęć w teorii prawdopodobieństwa i statystyce. Za pomocą przyczyn losowych Kepler wyjaśnił eliptyczność orbit planetarnych, Kant i Laplace podzielali taki punkt widzenia, mimo iż Newton wykazał zależność eliptyczności od prędkości ruchu planet.

Słowa kluczowe: prawa Keplera, orbity planet, losowość i konieczność, spontaniczność powstawania, systemy świata. 